
\title{
25 Research Soure \\ Universal Fragment of mtDNA for Cervidae and Other Ungulate Species Identification
}

Ewa Filip ( $\nabla$ ewa.filip@usz.edu.pl )

University of Szczecin https://orcid.org/0000-0003-2313-8398

\section{Tomasz Strzała}

Uniwersity Enviromental of Life Sciences

\section{Edyta Stępień}

University of Szczecin

Klaudia Pizoń

University of szczecin

\section{Research note}

Keywords: Molecular biology, mtDNA, Cervidae, Cytb, Capreolus capreolus, Dama dama, Cervus elaphus

Posted Date: December 4th, 2020

DOI: https://doi.org/10.21203/rs.3.rs-117242/v1

License: (c) (1) This work is licensed under a Creative Commons Attribution 4.0 International License.

Read Full License 


\section{Abstract}

\section{Objective}

The abundance of literature and many studies aimed at the identification of free-living animal species has helped to identify specific nucleotide marker sequences. In many cases, the best marker to distinguish species is the mitochondrial genome (mtDNA) or one of its fragments. In molecular analyses of Cervidae, biological material such as blood or muscle is easily obtained, as nearly all of these species are gaming animals.

\section{Results}

In our research, we present the case study of successful species identification based on degraded samples of bone, with the use of short mtDNA fragments. We obtained a partial sequence of the mitochondrial cytochrome b (Cytb) gene for Capreolus capreolus, Dama dama, and Cervus elaphus, that can be used for species affiliation. The proposed methodology is helpful as a routine identification procedure for a variety of tissue sources, even in cases where the samples are degraded. The new sequences have been deposited in GenBank, enriching the existing Cervidae mtDNA base.

\section{Introduction}

The current state of knowledge of molecular biologists has led to the widespread use of mitochondrial DNA (mtDNA) as a marker for species specific identification in animals [1-5] . For intraspecific detection of unrelated individuals, sequences with high variability are recommended, e.g. certain nuclear genes [6]. For species identification within Cervidae, we choose conservative sequences shared among the animals with species specific variables, because doing so brings the best effect [7-9].

Mitochondrial DNA is known to be an effective molecular marker in phylogenetic analyses [10,11]. This is due to the high polymorphism of the control region, as well as a lack of recombination, and very good isolation efficiency, even from small amounts of biological tissue, as well as the resistance of mtDNA to degradation processes. The analysis of species-specific variation using the homologous cytochrome $b$ (Cytb) is characterized by high reproducibility and sensitivity of results [11-16]. To distinguish closely related species, selected mtDNA fragments with very high specificity are needed. Often conservative gene sequences encoding proteins are used in studies on interspecies diversity [17], while the control region is used to provide a reliable source of knowledge about intraspecific variability $[7,10,17]$.

Cytochrome $b$ provides excellent phylogenetic information on the taxonomic position of various vertebrates; it can be used in the analysis of live specimens or for forensic identification purposes [1821]. In addition, this gene is often considered when determining origins of samples from difficult biological materials, i.e. hair, feathers, tooth fragments or other bones, which mainly utilize mitochondrial DNA polymorphisms [18]. Irwin et al. [22] has determined the rate of evolutionary changes for the genera of some species in different components of cytochrome $b$ amino acid sequences based on fossil DNA analyses. Several recent studies show that when the DNA template is derived from bone material, a 300- 
500 bp Cytb fragment, is suitable for mammalian species identification [19, 23-26].

We have found the cytochrome $b$ mitochondrial gene to be useful in identifying species of wild animals using bone material (mandible, frontal bone). The aim of our research was to develop a short universal fragment from mtDNA, which could be used in the species identification of various deer populations.

\section{Methods}

\section{Sampling DNA}

Bones skull samples were obtained from wild populations of 3 ungulate species in 2016-2018. DNA isolations were performed using the column-based method and the GeneMatrix Bond DNA Purification Kit (Eurx). The purity and concentration of DNA from the bone material was determined using a NanoDrop 2000c spectrophotometer (Thermo Scientific).

\section{Mitochondrial DNA analysis}

The following primer pair was used for PCR amplification: Mcb_KPF398:GTCAACAAATCATAAAGATATTGG, Mcb_KPR869: AAACTTCAGGGTGACCAAAAAATCA. PCR reactions were performed in a total volume of $20 \mu \mathrm{l}$ consisting of $20 \mathrm{ng}$ of DNA, 1x DreamTaq Buffer with $\mathrm{MgCl}_{2}, 0.2 \mathrm{mM}$ dNTP, $0.2 \mu \mathrm{M}$ of each primer, and $1 \mathrm{U}$ DreamTaq DNA Polymerase (Thermo Scientific).

The thermal reaction profile used to amplify the $C y t b$ regions was as follows: initial denaturation at $95{ }^{\circ} \mathrm{C}$ for $2 \mathrm{~min}$ followed by 35 cycles of denaturation at $95^{\circ} \mathrm{C}$ for $30 \mathrm{~s}$, annealing at $58^{\circ} \mathrm{C}$ for $30 \mathrm{~s}$, extension of the primer at $72{ }^{\circ} \mathrm{C}$ for $30 \mathrm{~s}$, and a final extension of $72^{\circ} \mathrm{C}$ for $7 \mathrm{~min}$.

PCR products were checked by electrophoresis in a 1.5\% agarose gel containing ethidium bromide and a TBE buffer ( $\mathrm{pH}$ 8.0); the gels were visualized under UV and archived using the GeneSys V.1.3.5.0 software (Syngene). The sequences reported in this paper have been deposited in the GenBank nucleotide sequence database with the accession numbers in Table 2.

\section{Sequence Analysis}

At first, the forward and reverse sequences were edited, and consensus sequences were obtained using Basic Local Alignment Tool software. ClustalW and Mega7.1 software were used to perform multiple sequence alignments [27]. Substitution patterns and rates were estimated under the Kimura (1980) 2parameter model [28].

The genetic variability of haplotypes was characterized by the total alignment length (bp), the number of monomorphic sites, the number of polymorphic sites, the number of parsimony informative sites (PIC), the number of haplotypes, and the average $\mathrm{G}+\mathrm{C}$ content in each region using DnaSP6.10.01. [29]. 


\section{Species identification}

To reveal the species of each sample analysed, we performed phylogeny reconstruction using the Bayesian approach. Seven Cytb sequences for Cervus elaphus, two for Dama dama and 9 for Capreolus capreolus were grouped together along with 115 Cytb sequences (Table 2) of the three species from Genbank, as well as two outgroup sequences (Antidorcas marsupialis, Beatragus hunteri) for comparison. Next, all sequences were aligned with the Muscle algorithm [30] and cut to obtain the proper alignment set in Seaview [31]. The best-fit substitution model was chosen using jModelTest 2.10 [32]. Finally, the tree was constructed with MrBayes 3.2.6 [33] using two, randomly started and independent runs, carried out for 20,000,000 generations of Markov chain steps. A consensus tree was constructed based on the set of trees collected after both runs converged - i.e., when the standard deviation of both runs was much below 0.01 .

\section{Results}

\section{Isolation}

Table 1 showns a spectrophotometer readings on DNA isolates, gave OD 260/280 ratios ranging from 1.8 to 2.33 , for the 18 different bone fragments. Among the studied samples, values exceeding 2.0 were obtained for several samples: two fragments of red deer bone marked KBMICSZ3 (2.01), the fallow deer bone fragment KBMICSZ13 (2.21), and a fragment of roe deer frontal bone marked KBMICSZ25 (2.33).

\section{Species identification of analysed DNA sample}

As a result of performing PCR and DNA sequencing on the collected deer samples, 18 sequences of the Cytb gene were obtained, which helped in the identification of each species belonging to the Cervidae family. The frequencies for each nucleotide were as follows: $A=25 \%, T / U=25 \%, C=25 \%$, and $G=25 \%$. This analysis involved 18 nucleotide sequences with a total of 207 positions in the final dataset. The average GC content was $50 \%$. The Cytb region was characterized by a high level of monomorphism with a small number of 163 sites and polymorphic sites number of 44 and a number of parsimoniously informative sites number (PIC) of 2. Based on the whole length of the Cytb gene sequenced, a total of 5 haplotypes were detected with a Hd (Haplotype diversity) equal to 0.771 . The most frequent haplotype was Hap_3, which contained 7 species. It should be mentioned that the type of genetic frequency of these haplotypes in North-western Poland Cervidae haplotypes Hap_1: 5.6\% and Hap_2: 1.1\% for Cervus elaphus, Hap_3: $7.8 \%$ and Hap_4: 3.3\% for Capreolus capreolus, and Hap_5 was 2.2\% for Dama dama.

Figure 1 showns the obtained phylogenetic tree was resolved into three distinct clades that consisted of representatives of the three analysed species. Samples were grouped together with each species representatives showing a high probability $(100 \%)$ of assignment, indicating clear species identification. Within the clades we found substantial polytomy, which is a result of lack of sequence informativity within the species level. 


\section{Discussion}

At the beginning, it should be noted that DNA analysis of biological samples has become the standard practice in animal identification at various taxonomic levels. Different types of tissues, such as bones, blood, hair (fur), feathers, skin, meat (muscle sample), faecal, and others are often the subject of many studies in various DNA analysis laboratories [14,34].

The compilation of known DNA markers influenced the construction of the genetic map of Cervus elaphus [35-37]. This genetic map comprises 621 sites (length of $2532 \mathrm{cM}$, with average intervals of 5.7 $\mathrm{cM}$ ), and it integrates modern technologies and research methods, including: comparative genomics and orthologous alleles of DNA markers derived from ruminants and other mammals (i.e. Pere David's deer, Elaphurus davidianus and red deer, C. elaphus) [38]. The genetic map of deer was used as an annotation for further research, such as the origin and evolution of ruminant genomes [36], QTL scanning [37], SNP analyses of the whole genome, $[39,40]$ and whole genome sequencing as well as the annotation and assembly of pseudochromosomes [38].

Currently, a universal fragment of genetic information is constantly being sought to use in many areas, e.g. poaching [18,41,42], illicit trafficking of endangered species [18, 41-43], protection of endangered animal species [44], or determination of meat origin (for identification purposes) [43, 45]. Anna Ramon Laca et al. [14], showed differentiation of species can be achieved by using a species-specific primer that amplifies dissimilar length fragments.

The total length analysed for all tested individuals was $207 \mathrm{bp}$ due to the removal of the last nucleotides in the sequences. The reason for obtaining different lengths was probably due to inhibition of sequencing reactions by individual matrices. Similar results were obtained by Kumar Gupta [24], who worked on stool samples, and also obtained short Cytb sequence fragments of 366, 374 and 503 bp $[14,34,46]$.

We show that when using bone tissue, the primers used in this work for the Cytb gene fragment amplifications work better, because firstly, they differentiate closely related species well and have the additional advantage that they can be used for many other mammalian species as well. Our research is confirmed by many studies, not only for the family Cervidae, but also other works on the identification of wild mammalian species $[1,5,23,34,47,48]$.

There are differences of opinion among the researchers, regarding which of the markers, $\mathrm{COI}$ or Cytb, provides more reliable and reproducible results for DNA barcoding analysis. In 2010, a group of researchers led by Tobe [1] carried out an assessment of genetic intraspecific variability based on $\mathrm{COI}$ and Cytb sequences from 217 mammalian species. The results showed that the discriminatory power was higher for the $C y t b$ gene, i.e. there was a higher probability that two random individuals from a given population would have sequence differences at the marker locus than for the $\mathrm{CO} /$ sequence. Research carried out by Wilson-Wilde [49] demonstrated that identification based on the COI gene sequence is suitable for genetically distant species, while in the case of closely related species, it is no longer 
unambiguous and requires additional tests. However, $\mathrm{COI}, \mathrm{Cytb}$, and the mt-CR control region are more often used for this purpose $[1,12-16,47,50-52]$.

The phylogenetic analysis grouped the analysed sequences within individual species with $100 \%$ probability (Figure.1). The Cytb fragment, analysed in this study, allows correct species identification, however, the lack of intraspecific polymorphism results in the inability to use it in population studies. This is clearly shown in the phylogenetic tree obtained (Figure. 1) where most monospecific nodes are polytomous. Lack of the node's solution (polytomy) is in this case is the result of a lack of genetic information from the analysed DNA sequences (soft polytomy). Our results suggest that the intraspecific genetic polymorphism is low for all mammalian species. Similar results were obtained in earlier studies $[1,53]$.

\section{Conclusion}

Despite the challenging biological material of bone tissue, the Cytb gene was successfully used to identify individuals of closely related ungulate bone DNA species using PCR analysis and Sanger DNA sequencing. Our results contribute to the study of mitochondrial ungulates by providing new reference sequences that are available in a public database. The method reported here could readily be adapted to discriminate other mammalian species from bones DNA.

\section{Limitations}

The efficiency of the applied DNA isolation method varied. The resulting DNA concentration values demonstrated over a hundredfold difference between the lowest and highest concentration. The study revealed that one of the most important moments during the DNA extraction process was the preliminary preparation of the bone material. Identification of bones samples was depends on the quality and quantity of DNA present in the sample. Another major limitation of the study was the high ratios for isolates indicated they were contaminated with RNA.

\section{Abbreviations}

Not applicable.

\section{Declarations}

\section{Ethics approval and consent to participate}

The study material used consisted of selected parts of skeleton (mandible or skull bones) of three representatives from the Cervidae family: Red deer, Cervus elaphus; Roe deer, Capreolus capreolus; Fallow deer, Dama dama; provided to us by commercial hunters from land managed by the north-western Poland. All animals were harvested in accordance with normal recreational and commercial hunting 
practices as permitted by the Polish Department of Conservation. Under Poland law, Institutional Animal Ethics Committee approval was not required for this study because all samples were collected from animals harvested for management purposes.

\section{Consent to publish}

Not applicable.

\section{Availability of data and materials}

All data generated or analyzed during this study are included in this published article.

\section{Competing interests}

The authors declare that they have no competing interests

\section{Funding}

This work was supported by the Institute of Biology, University of Szczecin, Poland. The funding body provided only financial suport.

\section{Authors' contributions}

Ewa Filip - conceptualization, methodology, formal analysis, writing - original draft, review \& editing, supervision, validation, funding acquisition

Tomasz Strzała - conceptualization, data curation, investigation, formal analysis

Edyta Stępień - data curation, investigation

Klaudia Pizoń - data curation, investigation

\section{Acknowledgements}

Not applicable.

\section{References}

1. Tobe SS, Kitchener AC, Linacre AMT. Reconstructing mammalian phylogenies: A detailed comparison of the cytochrome $b$ and cytochrome oxidase subunit i mitochondrial genes. PLoS One. 
2010;5:e14156. doi:10.1371/journal.pone.0014156.

2. Nakaki S ichi, Hino D, Miyoshi M, Nakayama H, Moriyoshi H, Morikawa T, et al. Study of animal species (human, dog and cat) identification using a multiplex single-base primer extension reaction in the cytochrome b gene. Forensic Sci Int. 2007;173:97-102. doi:10.1016/j.forsciint.2007.02.010.

3. Wada K, Nishibori M, Yokohama M. The complete nucleotide sequence of mitochondrial genome in the Japanese Sika deer (Cervus nippon), and a phylogenetic analysis between Cervidae and Bovidae. Small Rumin Res. 2007;69:46-54.

4. Kuwayama R, Ozawa T. Phylogenetic relationships among European red deer, wapiti, and sika deer inferred from mitochondrial DNA sequences. Mol Phylogenet Evol. 2000;15:115-23.

5. Tobe SS, Linacre A. DNA typing in wildlife crime: Recent developments in species identification. Forensic Science, Medicine, and Pathology. 2010;6:195-206. doi:10.1007/s12024-010-9168-7.

6. Xavier MA, Pinto LR, Fávero TM, Perecin D, Carlini-Garcia LA, Landell MGA. Paternity identification in sugarcane polycrosses by using microsatellite markers. Genet Mol Res. 2014;13:2268-77. doi:10.4238/2014.March.31.7.

7. Ramos A, Santos C, Mateiu L, Gonzalez M del M, Alvarez L, Azevedo L, et al. Frequency and Pattern of Heteroplasmy in the Complete Human Mitochondrial Genome. PLoS One. 2013;8:e74636. doi:10.1371/journal.pone.0074636.

8. Knapik K, J囚drzejczak M, Dybus A. Mitochondrialny gen cytochromu b (MTCYB). Med Weter. 2006;62:1229-32.

9. Han S, Cho I, Lee S, Tandang L, Lee H, Oh H, et al. Identification of species and sex of Korean Roe Deer (Capreolus pygargus tianschanicus ) using SRY and CYTB genes . Integr Biosci. 2007;11:1658.

10. Holland MM, Parsons TJ. Mitochondrial DNA Sequence Analysis - Validation and Use for Forensic Casework. Forensic Sci Rev. 1999;11:21-50. http://www.ncbi.nlm.nih.gov/pubmed/26255820. Accessed 12 Oct 2020.

11. Lahiff S, Glennon M, Obrien L, Lyng J, Smith T, Maher M, et al. Species-specific PCR for the identification of ovine, porcine and chicken species in meat and bone meal (MBM). Mol Cell Probes. 2001;15:27-35.

12. Gilbert C, Ropiquet A, Hassanin A. Mitochondrial and nuclear phylogenies of Cervidae (Mammalia, Ruminantia): Systematics, morphology, and biogeography. Mol Phylogenet Evol. 2006;40:101-17.

13. GONZÁLEZ S, MALDONADO JE, ORTEGA J, TALARICO AC, BIDEGARAY-BATISTA L, GARCIA JE, et al. Identification of the endangered small red brocket deer (Mazama bororo) using noninvasive genetic techniques (Mammalia; Cervidae). Mol Ecol Resour. 2009;9:754-8. doi:10.1111/j.17550998.2008.02390.x.

14. Ramón-Laca A, Gleeson D, Yockney I, Perry M, Nugent G, Forsyth DM. Reliable discrimination of 10 ungulate species using high resolution melting analysis of Faecal DNA. PLoS One. 2014;9:e92043. doi:10.1371/journal.pone.0092043. 
15. Escobedo-Morales LA, Mandujano S, Eguiarte LE, Rodríguez-Rodríguez MA, Maldonado JE. First phylogenetic analysis of Mesoamerican brocket deer Mazama pandora and Mazama temama (Cetartiodactyla: Cervidae) based on mitochondrial sequences: Implications on Neotropical deer evolution. Mamm Biol. 2016;81:303-13.

16. Gutiérrez EE, Helgen KM, McDonough MM, Bauer F, Hawkins MTR, Escobedo-Morales LA, et al. A gene-tree test of the traditional taxonomy of american deer: The importance of voucher specimens, geographic data, and dense sampling. Zookeys. 2017;697:87-131. doi:10.3897/zookeys.697.15124.

17. Bruford MW, Bradley DG, Luikart G. DNA markers reveal the complexity of livestock domestication. Nature Reviews Genetics. 2003;4:900-10.

18. Parson W, Pegoraro K, Niederstätter H, Föger M, Steinlechner M. Species identification by means of the cytochrome b gene. Int J Legal Med. 2000;114:23-8.

19. Hsieh HM, Chiang HL, Tsai LC, Lai SY, Huang NE, Linacre A, et al. Cytochrome b gene for species identification of the conservation animals. Forensic Sci Int. 2001;122:7-18. doi:10.1016/S03790738(01)00403-0.

20. Xiao CT, Zhang MH, Fu Y, Koh HS. Mitochondrial DNA distinction of northeastern China roe deer, Siberian roe deer, and European roe deer, to clarify the taxonomic status of northeastern China roe deer. Biochem Genet. 2007;45:93-102. doi:10.1007/s10528-006-9052-z.

21. Guha S, Goyal SP, Kashyap VK. Molecular phylogeny of musk deer: A genomic view with mitochondrial 16S rRNA and cytochrome b gene. Mol Phylogenet Evol. 2007;42:585-97.

22. Irwin DM, Kocher TD, Wilson AC. Evolution of the cytochrome b gene of mammals. J Mol Evol. 1991;32:128-44. doi:10.1007/BF02515385.

23. Verma SK, Singh L. Novel universal primers establish identity of an enormous number of animal species for forensic application. Mol Ecol Notes. 2003;3:28-31.

24. Gupta SK, Kumar A, Hussain SA. Novel primers for sequencing of the complete mitochondrial cytochrome $b$ gene of ungulates using non-invasive and degraded biological samples. Conserv Genet Resour. 2014;6:499-501.

25. Ajmal Ali M, Gyulai G, Hidvégi N, Kerti B, Al Hemaid FMA, Pandey AK, et al. The changing epitome of species identification - DNA barcoding. Saudi Journal of Biological Sciences. 2014;21:204-31. doi:10.1016/j.sjbs.2014.03.003.

26. Candan K, Kankılıç T, Güçlü Ö, Kumlutaş Y, Durmuş SH, Lymberakis P, et al. First assessment on the molecular phylogeny of Anatololacerta (Squamata, Lacertidae) distributed in Southern Anatolia: Insights from mtDNA and nDNA markers. Mitochondrial DNA Part A DNA Mapping, Seq Anal. 2016;27:2285-92. doi:10.3109/19401736.2014.987238.

27. Kumar S, Stecher G, Tamura K. MEGA7: Molecular Evolutionary Genetics Analysis Version 7.0 for Bigger Datasets. Mol Biol Evol. 2016;33:1870-4. doi:10.1093/molbev/msw054.

28. Edgar RC. MUSCLE: Multiple sequence alignment with high accuracy and high throughput. Nucleic Acids Res. 2004;32:1792-7. doi:10.1093/nar/gkh340. 
29. Librado P, Rozas J. DnaSP v5: A software for comprehensive analysis of DNA polymorphism data. Bioinformatics. 2009;25:1451-2. doi:10.1093/bioinformatics/btp187.

30. Edgar RC. MUSCLE: Multiple sequence alignment with high accuracy and high throughput. Nucleic Acids Res. 2004;32:1792-7. doi:10.1093/nar/gkh340.

31. Gouy M, Guindon S, Gascuel O. Sea view version 4: A multiplatform graphical user interface for sequence alignment and phylogenetic tree building. Mol Biol Evol. 2010;27:221-4. doi:10.1093/molbev/msp259.

32. Darriba D, Taboada GL, Doallo R, Posada D. JModelTest 2: More models, new heuristics and parallel computing. Nature Methods. 2012;9:772. doi:10.1038/nmeth.2109.

33. Ronquist F, Teslenko M, Van Der Mark P, Ayres DL, Darling A, Höhna S, et al. Mrbayes 3.2: Efficient bayesian phylogenetic inference and model choice across a large model space. Syst Biol. 2012;61:539-42.

34. Panday R, K. Jha D, Thapa N, R. Pokharel B, K. Aryal N. Forensic Wildlife Parts and their Product Identification and Individualization Using DNA Barcoding. Open Forensic Sci J. 2015;7:6-13.

35. Tate ML, Mathias HC, Fennessy PF, Dodds KG, Penty JM, Hill DF. A new gene mapping resource: Interspecies hybrids between Pere David's deer (Elaphurus davidianus) and red deer (Cervus elaphus). Genetics. 1995;139:1383-91.

36. Slate J, Van Stijn TC, Anderson RM, Mary McEwan K, Maqbool NJ, Mathias HC, et al. A deer (subfamily cervinae) genetic linkage map and the evolution of ruminant genomes. Genetics. 2002;160:1587-97.

37. Slate J, Visscher PM, MacGregor S, Stevens D, Tate ML, Pembertont JM. A genome scan for quantitative trait loci in a wild population of red deer (Cervus elaphus). Genetics. 2002;162:1863-73. www.thearkdb.org/browser?speciescow. Accessed 10 Oct 2020.

38. Bana N, Nyiri A, Nagy J, Frank K, Nagy T, Stéger V, et al. The red deer Cervus elaphus genome CerEla1.0: sequencing, annotating, genes, and chromosomes. Mol Genet Genomics. 2018;293:66584. doi:10.1007/s00438-017-1412-3.

39. Brauning R, Fisher P, McCulloch A, Smithies R, Ward J, Bixley M, et al. Utilization of high throughput genome sequencing technology for large scale single nucleotide polymorphism discovery in red deer and Canadian elk. bioRxiv. 2015;:027318. doi:10.1101/027318.

40. Johnston S, Huisman J, Ellis P, Pemberton J. A high density linkage map reveals sexual dimorphism in recombination landscapes in red deer (Cervus elaphus ). A high-density Link map Reveal Sex dimorphism Recomb landscapes red deer (Cervus elaphus). 2017;:100131. doi:10.1101/100131.

41. Lopez-Oceja A, Gamarra D, Borragan S, Jiménez-Moreno S, De Pancorbo MM. New cyt b gene universal primer set for forensic analysis. Forensic Sci Int Genet. 2016;23:159-65. doi:10.1016/j.fsigen.2016.05.001.

42. Jun J, Han SH, Jeong TJ, Park HC, Lee B, Kwak M. 721-726 Wildlife forensics using mitochondrial DNA sequences: Species identification based on hairs collected in the field and confiscated tanned Felidae leathers. Genes and Genomics. 2011;33:721-6. doi:10.1007/s13258-011-0080-7. 
43. Tobe SS, Linacre AMT. A multiplex assay to identify 18 European mammal species from mixtures using the mitochondrial cytochrome b gene. Electrophoresis. 2008;29:340-7. doi:10.1002/elps.200700706.

44. Hsieh HM, Chiang HL, Tsai LC, Lai SY, Huang NE, Linacre A, et al. Cytochrome b gene for species identification of the conservation animals. Forensic Sci Int. 2001;122:7-18. doi:10.1016/S03790738(01)00403-0.

45. Spychaj A, Mozdziak PE, Pospiech E. PCR METHODS IN MEAT SPECIES IDENTIFICATION AS A TOOL FOR THE VERIFICATION OF REGIONAL AND TRADITIONAL MEAT PRODUCTS. ACTA Acta Sci Pol, Technol Aliment. 2009;8:5-20. www.food.actapol.net. Accessed 10 Oct 2020.

46. Baker KH, Gray HWI, Ramovs V, Mertzanidou D, Akin Pekşen, Bilgin CC, et al. Strong population structure in a species manipulated by humans since the Neolithic: The European fallow deer (Dama dama dama). Heredity (Edinb). 2017;119:16-26. doi:10.1038/hdy.2017.11.

47. Kang M, Han S, Jung Y, Oh J, Kim G, Ko J, et al. Genetic analysis of ancient bones of Cervidae animals from archaeological site in Jeju, Korea. Integr Biosci. 2007;11:147-53. doi:10.1080/17386357.2007.9647328.

48. Polziehn RO, Strobeck C. A phylogenetic comparison of red deer and wapiti using mitochondrial DNA. Mol Phylogenet Evol. 2002;22:342-56.

49. Wilson-Wilde L, Norman J, Robertson J, Sarre S, Georges A. Current issues in species identification for forensic science and the validity of using the cytochrome oxidase I (COI) gene. Forensic Sci Med Pathol. 2010;6:233-41.

50. Andrejevic M, Markovic MK, Bursac B, Mihajlovic M, Tanasic V, Kecmanovic M, et al. Identification of a broad spectrum of mammalian and avian species using the short fragment of the mitochondrially encoded cytochrome b gene. Forensic Sci Med Pathol. 2019;15:169-77.

51. Borowski Z, Świsłocka M, Matosiuk M, Mirski P, Krysiuk K, Czajkowska M, et al. Purifying Selection, Density Blocking and Unnoticed Mitochondrial DNA Diversity in the Red Deer, Cervus elaphus. PLoS One. 2016;11:e0163191. doi:10.1371/journal.pone.0163191.

52. Muangkram $\mathrm{Y}$, Wajjwalku W, Amano A, Sukmak M. The novel primers for mammal species identification-based mitochondrial cytochrome $b$ sequence: implication for reserved wild animals in Thailand and endangered mammal species in Southeast Asia. Mitochondrial DNA Part A DNA Mapping, Seq Anal. 2018;29:62-72.

53. Lorenzini R, Garofalo L, Qin X, Voloshina I, Lovari S. Global phylogeography of the genus Capreolus (Artiodactyla: Cervidae), a Palaearctic meso-mammal. Zool J Linn Soc. 2014;170:209-21.

\section{Tables}

Table 1. List of the study materials and results of DNA isolations. 


\begin{tabular}{|c|c|c|c|c|c|c|}
\hline No. & Sample ID & Species & $\begin{array}{l}\text { Type of } \\
\text { bone }\end{array}$ & $\begin{array}{l}\text { Weight } \\
\text { [g] }\end{array}$ & $\begin{array}{l}\text { DNA concentration } \\
[\mathrm{ng} / \mu \mathrm{l})]\end{array}$ & $\begin{array}{l}\text { A260/A280 } \\
\text { ratio }\end{array}$ \\
\hline 1. & KBMICSZ1 & Red deer & Mandible & 0.28 & 216.8 & 1.95 \\
\hline 2. & KBMICSZ2 & Red deer & Mandible & 0.26 & 386.0 & 1.85 \\
\hline 3. & KBMICSZ3 & Red deer & Mandible & 0.26 & 91.1 & 2.01 \\
\hline 4. & KBMICSZ9 & Red deer & Mandible & 0.35 & 142.8 & 1.85 \\
\hline 5. & KBMICSZ20 & Red deer & Mandible & 0.24 & 259.8 & 1.83 \\
\hline 6. & KBMICSZ4 & Red deer & Mandible & 0.38 & 180.2 & 1.87 \\
\hline 7. & KBMICSZ5 & Roe deer & $\begin{array}{l}\text { Frontal } \\
\text { bone }\end{array}$ & 0.36 & 1264.2 & 1.82 \\
\hline 8. & KBMICSZ6 & Roe deer & $\begin{array}{l}\text { Frontal } \\
\text { bone }\end{array}$ & 0.34 & 661.8 & 1.83 \\
\hline 9. & KBMICSZ8 & Roe deer & $\begin{array}{l}\text { Frontal } \\
\text { bone }\end{array}$ & 0.28 & 187.8 & 1.85 \\
\hline 10. & KBMICSZ14 & Roe deer & $\begin{array}{l}\text { Frontal } \\
\text { bone }\end{array}$ & 0.35 & 474.0 & 1.85 \\
\hline 11. & KBMICSZ15 & Roe deer & $\begin{array}{l}\text { Frontal } \\
\text { bone }\end{array}$ & 0.36 & 242.3 & 1.88 \\
\hline 12. & KBMICSZ16 & Roe deer & $\begin{array}{l}\text { Frontal } \\
\text { bone }\end{array}$ & 0.39 & 289.4 & 1.86 \\
\hline 13. & KBMICSZ21 & Roe deer & $\begin{array}{l}\text { Frontal } \\
\text { bone }\end{array}$ & 0.30 & 782.9 & 1.81 \\
\hline 14. & KBMICSZ22 & Roe deer & $\begin{array}{l}\text { Frontal } \\
\text { bone }\end{array}$ & 0.30 & 123.2 & 1.87 \\
\hline 15. & KBMICSZ24 & Roe deer & $\begin{array}{l}\text { Frontal } \\
\text { bone }\end{array}$ & 0.30 & 119.1 & 1.97 \\
\hline 16. & KBMICSZ25 & Roe deer & $\begin{array}{l}\text { Frontal } \\
\text { bone }\end{array}$ & 0.30 & 12.9 & 2.33 \\
\hline 17. & KBMICSZ7 & $\begin{array}{l}\text { Fallow } \\
\text { deer }\end{array}$ & Mandible & 0.33 & 353.7 & 1.83 \\
\hline 18. & KBMICSZ13 & $\begin{array}{l}\text { Fallow } \\
\text { deer }\end{array}$ & Mandible & 0.28 & 12.5 & 2.21 \\
\hline
\end{tabular}

Note: The place of collection samples: No. 1-6 and 17-18Plecemin: 53016'31.931" N 16048'30.246" E; No. 7-8

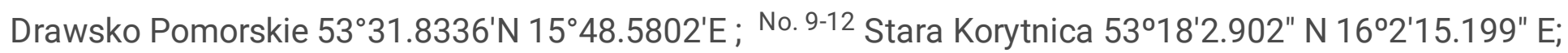
No. 13-14 Karwowo5341'26.002" N 15³3'2.002" E; No. 15-16 Dorowo 53²43'20.775" N 15²27'26.097" E 
Table 2. Cytb sequences obtained from Genbank and used in a phylogenetic reconstruction. 


\begin{tabular}{|c|c|c|c|}
\hline Species & $\begin{array}{l}\text { Accession number in } \\
\text { GenBank/*Sequences number in } \\
\text { this work }\end{array}$ & Species & $\begin{array}{l}\text { Accession number in } \\
\text { GenBank/*Sequences number in } \\
\text { this work }\end{array}$ \\
\hline $\begin{array}{l}\text { Cervus } \\
\text { elaphus }\end{array}$ & KX449334 & $\begin{array}{l}\text { Cervus } \\
\text { elaphus }\end{array}$ & KX389327 \\
\hline $\begin{array}{l}\text { Cervus } \\
\text { elaphus }\end{array}$ & MF872249 & $\begin{array}{l}\text { Cervus } \\
\text { elaphus }\end{array}$ & KJ138178 \\
\hline $\begin{array}{l}\text { Cervus } \\
\text { elaphus }\end{array}$ & KM410142 & $\begin{array}{l}\text { Cervus } \\
\text { elaphus }\end{array}$ & KX389324 \\
\hline $\begin{array}{l}\text { Cervus } \\
\text { elaphus }\end{array}$ & KJ138187 & $\begin{array}{l}\text { Cervus } \\
\text { elaphus }\end{array}$ & KX096849 \\
\hline $\begin{array}{l}\text { Cervus } \\
\text { elaphus }\end{array}$ & KC181335 & $\begin{array}{l}\text { Cervus } \\
\text { elaphus }\end{array}$ & HM596028 \\
\hline $\begin{array}{l}\text { Cervus } \\
\text { elaphus }\end{array}$ & JX966179 & $\begin{array}{l}\text { Cervus } \\
\text { elaphus }\end{array}$ & KJ138179 \\
\hline $\begin{array}{l}\text { Cervus } \\
\text { elaphus }\end{array}$ & JX966169 & $\begin{array}{l}\text { Cervus } \\
\text { elaphus }\end{array}$ & KJ138182 \\
\hline $\begin{array}{l}\text { Cervus } \\
\text { elaphus }\end{array}$ & JX966167 & $\begin{array}{l}\text { Cervus } \\
\text { elaphus }\end{array}$ & EU834880 \\
\hline $\begin{array}{l}\text { Cervus } \\
\text { elaphus }\end{array}$ & HQ122584 & $\begin{array}{l}\text { Cervus } \\
\text { elaphus } \\
\text { alxaicus }\end{array}$ & KU942399 \\
\hline $\begin{array}{l}\text { Cervus } \\
\text { elaphus }\end{array}$ & EU004023 & $\begin{array}{l}\text { Cervus } \\
\text { elaphus } \\
\text { xanthopygus }\end{array}$ & KM410148 \\
\hline $\begin{array}{l}\text { Cervus } \\
\text { elaphus }\end{array}$ & EU004020 & $\begin{array}{l}\text { Cervus } \\
\text { elaphus } \\
\text { kansuensis }\end{array}$ & NC39923 \\
\hline $\begin{array}{l}\text { Cervus } \\
\text { elaphus }\end{array}$ & AY044860 & $\begin{array}{l}\text { Cervus } \\
\text { elaphus } \\
\text { xanthopygus }\end{array}$ & JF893494 \\
\hline $\begin{array}{l}\text { Cervus } \\
\text { elaphus }\end{array}$ & AB924664 & $\begin{array}{l}\text { Cervus } \\
\text { elaphus } \\
\text { macneilli }\end{array}$ & AY035875 \\
\hline $\begin{array}{l}\text { Cervus } \\
\text { elaphus }\end{array}$ & MF872241 & $\begin{array}{l}\text { Cervus } \\
\text { elaphus } \\
\text { wallichi }\end{array}$ & FJ611889 \\
\hline $\begin{array}{l}\text { Cervus } \\
\text { elaphus }\end{array}$ & MF872242 & $\begin{array}{l}\text { Cervus } \\
\text { elaphus } \\
\text { canadensis }\end{array}$ & AB021096 \\
\hline $\begin{array}{l}\text { Cervus } \\
\text { elaphus }\end{array}$ & KX496944 & $\begin{array}{l}\text { Cervus } \\
\text { elaphus } \\
\text { bactrianus }\end{array}$ & JF893495 \\
\hline
\end{tabular}




\begin{tabular}{|c|c|c|c|}
\hline $\begin{array}{l}\text { Cervus } \\
\text { elaphus }\end{array}$ & KC562170 & $\begin{array}{l}\text { Cervus } \\
\text { elaphus } \\
\text { yarkandensis }\end{array}$ & AY142327 \\
\hline $\begin{array}{l}\text { Cervus } \\
\text { elaphus }\end{array}$ & KJ138185 & $\begin{array}{l}\text { Cervus } \\
\text { elaphus }\end{array}$ & AY142326 \\
\hline $\begin{array}{l}\text { Cervus } \\
\text { elaphus }\end{array}$ & EF139146 & Dama dama & KX550269 \\
\hline $\begin{array}{l}\text { Cervus } \\
\text { elaphus }\end{array}$ & AF489281 & Dama dama & AJ000022 \\
\hline $\begin{array}{l}\text { Cervus } \\
\text { elaphus }\end{array}$ & AY148966 & Dama dama & KX550269 \\
\hline $\begin{array}{l}\text { Cervus } \\
\text { elaphus }\end{array}$ & AB001612 & Dama dama & AJ000022 \\
\hline $\begin{array}{l}\text { Cervus } \\
\text { elaphus }\end{array}$ & KY313824 & Dama dama & JF304939 \\
\hline $\begin{array}{l}\text { Cervus } \\
\text { elaphus }\end{array}$ & KX389318 & Dama dama & X56290 \\
\hline $\begin{array}{l}\text { Cervus } \\
\text { elaphus }\end{array}$ & KJ138177 & Dama dama & *MK575604 \\
\hline $\begin{array}{l}\text { Cervus } \\
\text { elaphus }\end{array}$ & JX966177 & Dama dama & *MK575605 \\
\hline $\begin{array}{l}\text { Cervus } \\
\text { elaphus }\end{array}$ & JX966157 & $\begin{array}{l}\text { Capreolus } \\
\text { capreolus }\end{array}$ & KT964412 \\
\hline $\begin{array}{l}\text { Cervus } \\
\text { elaphus }\end{array}$ & JX966141 & $\begin{array}{l}\text { Capreolus } \\
\text { capreolus }\end{array}$ & KT964405 \\
\hline $\begin{array}{l}\text { Cervus } \\
\text { elaphus }\end{array}$ & JX966135 & $\begin{array}{l}\text { Capreolus } \\
\text { capreolus }\end{array}$ & KT964399 \\
\hline $\begin{array}{l}\text { Cervus } \\
\text { elaphus }\end{array}$ & JF489133 & $\begin{array}{l}\text { Capreolus } \\
\text { capreolus }\end{array}$ & KJ681480 \\
\hline $\begin{array}{l}\text { Cervus } \\
\text { elaphus }\end{array}$ & KX868591 & $\begin{array}{l}\text { Capreolus } \\
\text { capreolus }\end{array}$ & KJ558315 \\
\hline $\begin{array}{l}\text { Cervus } \\
\text { elaphus }\end{array}$ & KY313826 & $\begin{array}{l}\text { Capreolus } \\
\text { capreolus }\end{array}$ & KJ558308 \\
\hline $\begin{array}{l}\text { Cervus } \\
\text { elaphus }\end{array}$ & KY313823 & $\begin{array}{l}\text { Capreolus } \\
\text { capreolus }\end{array}$ & KJ558305 \\
\hline $\begin{array}{l}\text { Cervus } \\
\text { elaphus }\end{array}$ & KX389323 & $\begin{array}{l}\text { Capreolus } \\
\text { capreolus }\end{array}$ & KJ558303 \\
\hline $\begin{array}{l}\text { Cervus } \\
\text { elaphus }\end{array}$ & KC562186 & $\begin{array}{l}\text { Capreolus } \\
\text { capreolus }\end{array}$ & KJ558301 \\
\hline
\end{tabular}




\begin{tabular}{|c|c|c|c|}
\hline $\begin{array}{l}\text { Cervus } \\
\text { elaphus }\end{array}$ & KC181322 & $\begin{array}{l}\text { Capreolus } \\
\text { capreolus }\end{array}$ & KJ558296 \\
\hline $\begin{array}{l}\text { Cervus } \\
\text { elaphus }\end{array}$ & KC181316 & $\begin{array}{l}\text { Capreolus } \\
\text { capreolus }\end{array}$ & KJ558290 \\
\hline $\begin{array}{l}\text { Cervus } \\
\text { elaphus }\end{array}$ & JX966184 & $\begin{array}{l}\text { Capreolus } \\
\text { capreolus }\end{array}$ & KX550268 \\
\hline $\begin{array}{l}\text { Cervus } \\
\text { elaphus }\end{array}$ & JX966153 & $\begin{array}{l}\text { Capreolus } \\
\text { capreolus }\end{array}$ & *MK575596 \\
\hline $\begin{array}{l}\text { Cervus } \\
\text { elaphus }\end{array}$ & JX966142 & $\begin{array}{l}\text { Capreolus } \\
\text { capreolus }\end{array}$ & *MK575597 \\
\hline $\begin{array}{l}\text { Cervus } \\
\text { elaphus }\end{array}$ & AY044857 & $\begin{array}{l}\text { Capreolus } \\
\text { capreolus }\end{array}$ & *MK575606 \\
\hline $\begin{array}{l}\text { Cervus } \\
\text { elaphus }\end{array}$ & AF423195 & $\begin{array}{l}\text { Capreolus } \\
\text { capreolus }\end{array}$ & *MK575598 \\
\hline $\begin{array}{l}\text { Cervus } \\
\text { elaphus }\end{array}$ & KX868589 & $\begin{array}{l}\text { Capreolus } \\
\text { capreolus }\end{array}$ & *MK575599 \\
\hline $\begin{array}{l}\text { Cervus } \\
\text { elaphus }\end{array}$ & KY313820 & $\begin{array}{l}\text { Capreolus } \\
\text { capreolus }\end{array}$ & *MK575600 \\
\hline $\begin{array}{l}\text { Cervus } \\
\text { elaphus }\end{array}$ & KY313816 & $\begin{array}{l}\text { Capreolus } \\
\text { capreolus }\end{array}$ & *MK575601 \\
\hline $\begin{array}{l}\text { Cervus } \\
\text { elaphus }\end{array}$ & KC562187 & $\begin{array}{l}\text { Capreolus } \\
\text { capreolus }\end{array}$ & *MK575602 \\
\hline $\begin{array}{l}\text { Cervus } \\
\text { elaphus }\end{array}$ & KC181336 & $\begin{array}{l}\text { Capreolus } \\
\text { capreolus }\end{array}$ & *MK575603 \\
\hline $\begin{array}{l}\text { Cervus } \\
\text { elaphus }\end{array}$ & JX966143 & $\begin{array}{l}\text { Capreolus } \\
\text { capreolus }\end{array}$ & KJ558294 \\
\hline $\begin{array}{l}\text { Cervus } \\
\text { elaphus }\end{array}$ & *MK575589 & $\begin{array}{l}\text { Capreolus } \\
\text { capreolus }\end{array}$ & KT964435 \\
\hline $\begin{array}{l}\text { Cervus } \\
\text { elaphus }\end{array}$ & *MK575590 & $\begin{array}{l}\text { Capreolus } \\
\text { capreolus }\end{array}$ & Y14951 \\
\hline $\begin{array}{l}\text { Cervus } \\
\text { elaphus }\end{array}$ & *MK575591 & $\begin{array}{l}\text { Capreolus } \\
\text { capreolus }\end{array}$ & KT964407 \\
\hline $\begin{array}{l}\text { Cervus } \\
\text { elaphus }\end{array}$ & *MK575592 & $\begin{array}{l}\text { Capreolus } \\
\text { capreolus }\end{array}$ & KT964434 \\
\hline $\begin{array}{l}\text { Cervus } \\
\text { elaphus }\end{array}$ & *MK575593 & $\begin{array}{l}\text { Capreolus } \\
\text { capreolus }\end{array}$ & KT964400 \\
\hline $\begin{array}{l}\text { Cervus } \\
\text { elaphus }\end{array}$ & *MK575594 & $\begin{array}{l}\text { Capreolus } \\
\text { capreolus }\end{array}$ & KJ558329 \\
\hline $\begin{array}{l}\text { Cervus } \\
\text { elaphus }\end{array}$ & *MK575595 & $\begin{array}{l}\text { Capreolus } \\
\text { capreolus }\end{array}$ & KT964409 \\
\hline
\end{tabular}




\begin{tabular}{|llll|}
\hline $\begin{array}{l}\text { Cervus } \\
\text { elaphus }\end{array}$ & $\mathrm{AY} 070222$ & $\begin{array}{l}\text { Capreolus } \\
\text { capreolus }\end{array}$ & $\mathrm{KT} 964439$ \\
\hline $\begin{array}{l}\text { Cervus } \\
\text { elaphus }\end{array}$ & $\mathrm{KY} 313810$ & $\begin{array}{l}\text { Capreolus } \\
\text { capreolus }\end{array}$ & $\mathrm{KJ} 558326$ \\
$\begin{array}{l}\text { Cervus } \\
\text { elaphus }\end{array}$ & $\mathrm{AY} 118199$ & $\begin{array}{l}\text { Capreolus } \\
\text { capreolus }\end{array}$ & $\mathrm{KT} 964424$ \\
$\begin{array}{l}\text { Cervus } \\
\text { elaphus }\end{array}$ & $\mathrm{AY} 244489$ & $\begin{array}{l}\text { Capreolus } \\
\text { capreolus }\end{array}$ & $\mathrm{AJ} 000024$ \\
\hline $\begin{array}{l}\text { Cervus } \\
\text { elaphus }\end{array}$ & $\mathrm{MF} 872245$ & $\begin{array}{l}\text { Capreolus } \\
\text { capreolus }\end{array}$ & $\mathrm{KT} 964433$ \\
$\begin{array}{l}\text { Cervus } \\
\text { elaphus }\end{array}$ & $\mathrm{KX} 389317$ & $\begin{array}{l}\text { Capreolus } \\
\text { capreolus }\end{array}$ & $\mathrm{KT} 964431$ \\
$\begin{array}{l}\text { Cervus } \\
\text { elaphus }\end{array}$ & $\mathrm{EU} 878391$ & $\begin{array}{l}\text { Capreolus } \\
\text { capreolus }\end{array}$ & $\mathrm{KT} 964427$ \\
\hline $\begin{array}{l}\text { Cervus } \\
\text { elaphus }\end{array}$ & $\mathrm{KX} 389329$ & $\begin{array}{l}\text { Capreolus } \\
\text { capreolus }\end{array}$ & $\mathrm{KT} 964425$ \\
\hline $\begin{array}{l}\text { Cervus } \\
\text { elaphus }\end{array}$ & $\mathrm{KP} 859325$ & $\begin{array}{l}\text { Capreolus } \\
\text { capreolus }\end{array}$ & $\mathrm{KT} 964414$ \\
\hline $\begin{array}{l}\text { Cervus } \\
\text { elaphus }\end{array}$ & $\mathrm{KX} 389331$ & $\begin{array}{l}\text { Capreolus } \\
\text { capreolus }\end{array}$ & $\mathrm{KM} 224365$ \\
\hline $\begin{array}{l}\text { Cervus } \\
\text { elaphus }\end{array}$ & $\mathrm{AF} 423197$ & & \\
\hline
\end{tabular}

\section{Figures}




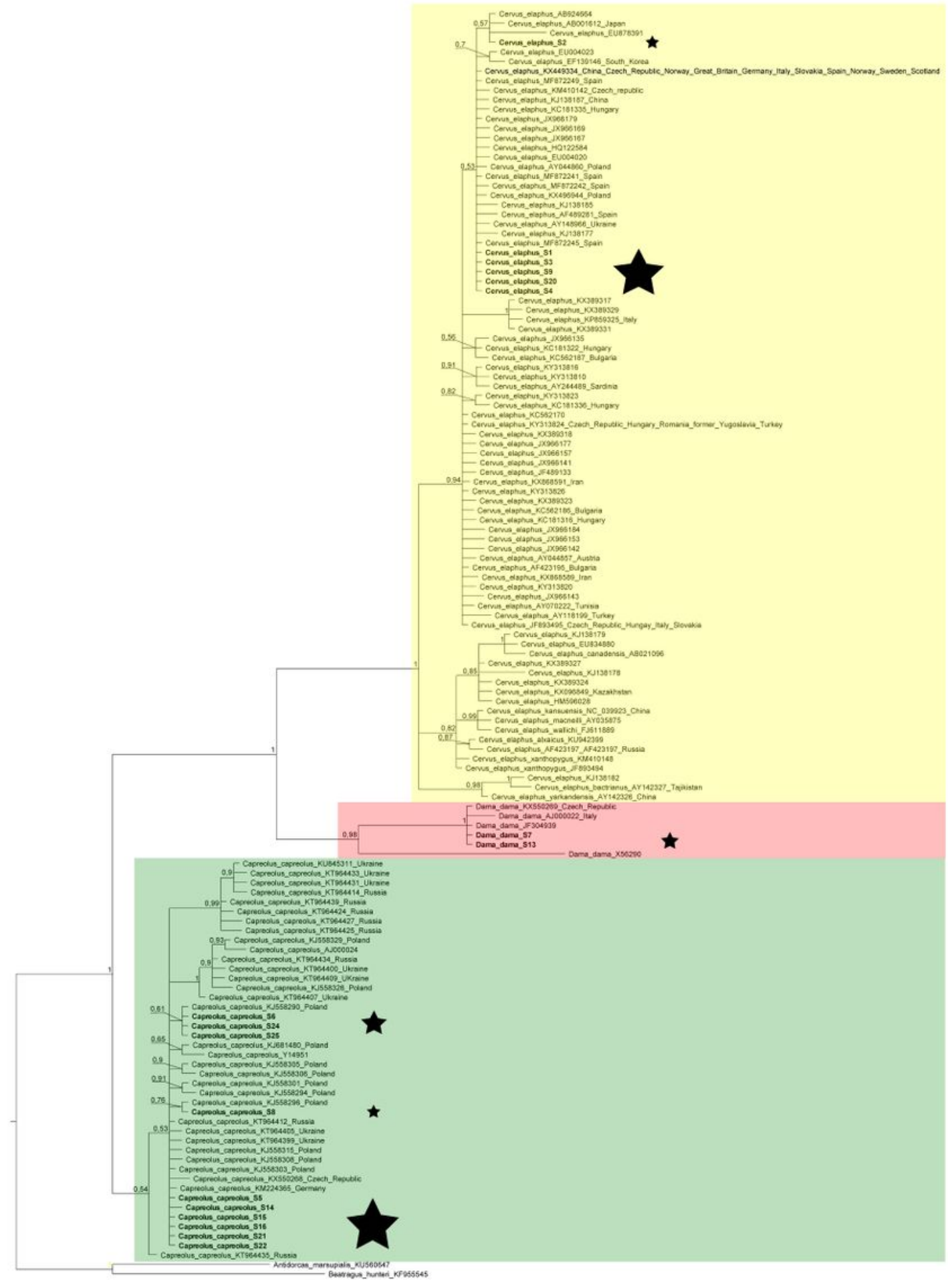

\section{Figure 1}

Bayesian phylogenetic tree showing species identification of analysed DNA samples (samples are indicated with a star). Sequences of Antidorcas marsupialis and Beatragus hunteri were used for rooting. Numbers along node are the posterior probability values of nodes. 


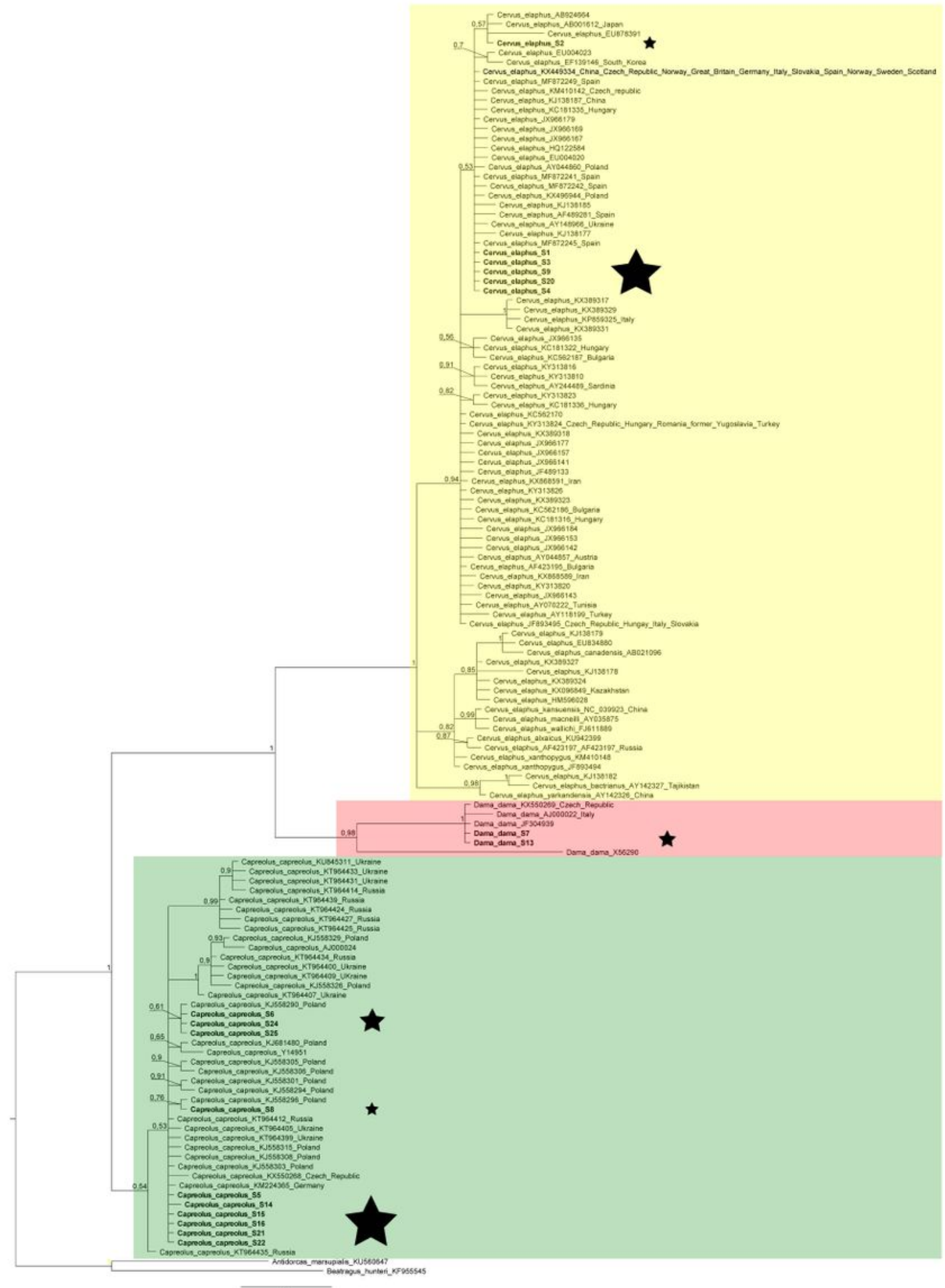

\section{Figure 1}

Bayesian phylogenetic tree showing species identification of analysed DNA samples (samples are indicated with a star). Sequences of Antidorcas marsupialis and Beatragus hunteri were used for rooting. Numbers along node are the posterior probability values of nodes. 


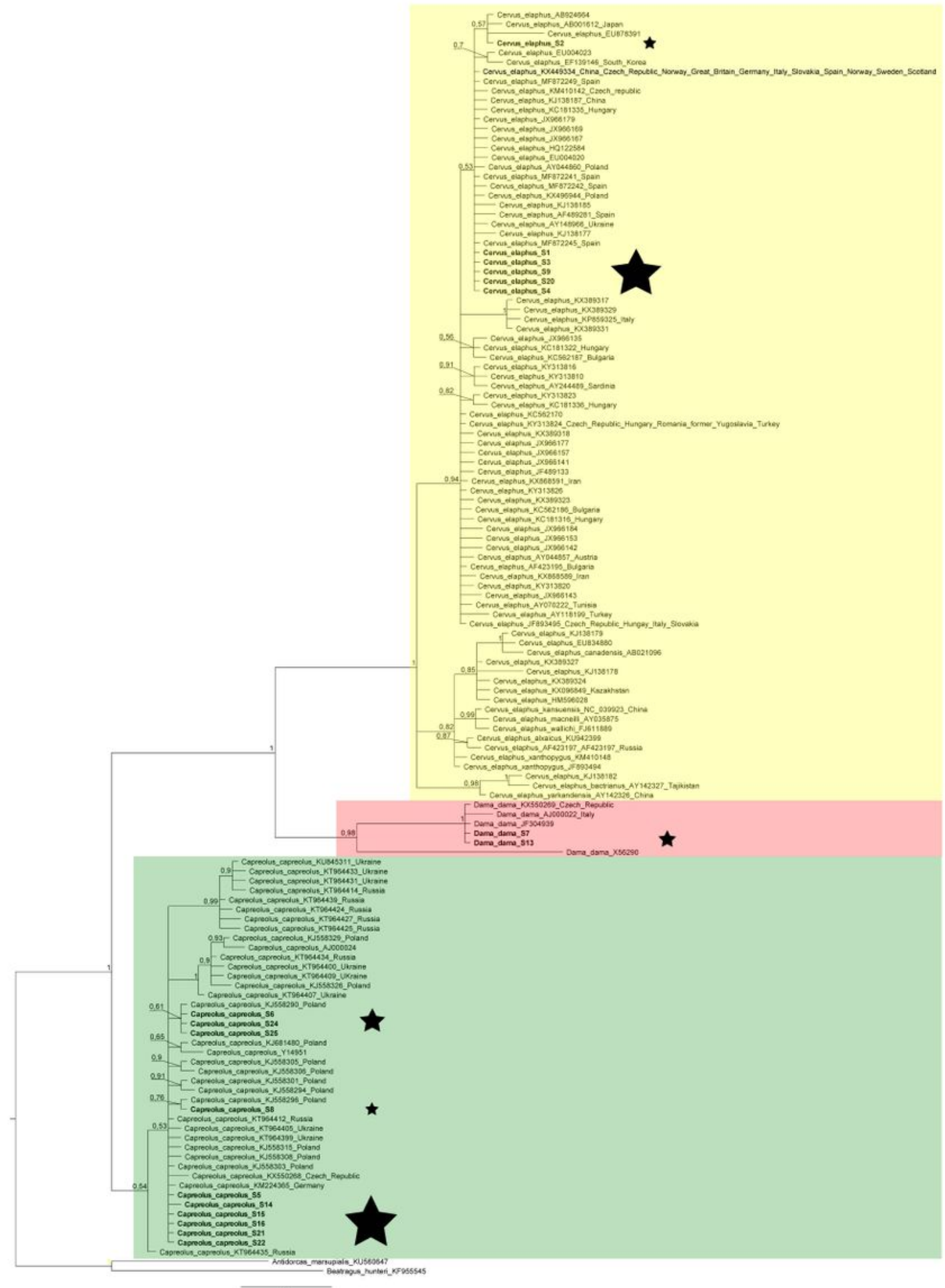

\section{Figure 1}

Bayesian phylogenetic tree showing species identification of analysed DNA samples (samples are indicated with a star). Sequences of Antidorcas marsupialis and Beatragus hunteri were used for rooting. Numbers along node are the posterior probability values of nodes. 